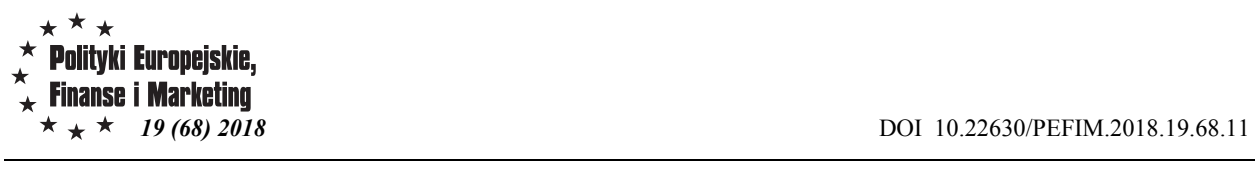

Agata Marcysiak

Uniwersytet Przyrodniczo-Humanistyczny w Siedlcach

Adam Marcysiak

Uniwersytet Przyrodniczo-Humanistyczny w Siedlcach

\title{
Efektywność wykorzystania zasobów w różnych typach gospodarstwach
}

\section{EFFECTIVENESS OF RESOURCE USE IN VARIOUS TYPES OF FARMS}

Typ rolniczy stanowi jedno z kryteriów używanych dla charakteryzowania gospodarstwa rolnego w UE. Celem niniejszego opracowania jest próba ukazania zakresu efektywności wykorzystania zasobów produkcyjnych $w$ różnych typach gospodarstw. Do oceny efektywności gospodarowania $w$ poszczególnych typach gospodarstw postużono się produktywnościq $i$ dochodowościq ziemi, pracy i kapitału. Poszczególne wielkości ukazano w przeliczeniu na jedno gospodarstwo w zł. Skalę zróżnicowania przedstawiono w ujęciu procentowym. Przeprowadzona analiza wykazała, $i z$ intensywna produkcja prowadzona $w$ gospodarstwach drobiarskich $i$ ogrodniczych sprawiała że to wtaśnie one osiagnęty w 2016 roku najwyższa produktywność i dochodowość ziemi i kapitału.

Słowa kluczowe: typ rolniczy, produktywność, dochodowość.

\section{Wstęp}

Europejski system zbierania danych rachunkowych z gospodarstw rolnych FADN funkcjonuje na terenie 28 państw członkowskich. Unikalność FADN polega na tym, że gromadzi on dane zaliczane do grupy wrażliwych, które opisują sytuację ekonomiczną i finansową gospodarstw rolnych.

W polu obserwacji FADN znajdują się gospodarstwa towarowe. Minimalna wielkość ekonomiczna, po przekroczeniu której włącza się gospodarstwo rolne do pola obserwacji FADN, ustalana jest na podstawie analizy sum Standardowej Produkcji (SO) w poszczególnych klasach wielkości ekonomicznej. Z powodu istniejących różnic w strukturze agrarnej, progi wielkości ekonomicznej, wyznaczające minimalną wielkość gospodarstw rolnych włączanych do pola obserwacji FADN, są różne w poszczególnych państwach członkowskich UE ${ }^{1}$. W Polsce w 2016 roku jako minimalną wielkość gospodarstwa uznawanego za towarowe przyjęto wielkość SO równą 4000 euro.

Gospodarstwa rolne funkcjonujace na terenie Unii Europejskiej klasyfikowane sa najczęściej według dwóch kryteriów: typu rolniczego i wielkości ekonomicznej. Zadaniem Wspólnej Typologii Gospodarstw Rolnych (WTGR) jest dostarczenie narzędzia umożliwiającego na poziomie Wspólnoty przeprowadzanie analiz sytuacji

\footnotetext{
${ }^{1}$ Committee for the farm accountancy data network. Typology handbook. Brussels, 2016. s. 25-30.
} 
ekonomicznej gospodarstw rolnych $\mathrm{w}$ grupach o podobnym potencjale i kierunku produkcji ${ }^{2}$. Typologia ta umożliwia również porównywanie gospodarstw rolnych pomiędzy krajami członkowskimi, jak również poszczególnymi regionami $\mathrm{w}$ ramach tych krajów.

Typ rolniczy gospodarstwa rolnego określany jest na podstawie udziału wartości standardowej produkcji $\mathrm{z}$ poszczególnych działalności rolniczych $\mathrm{W}$ tworzeniu całkowitej wartości SO gospodarstwa ${ }^{3}$. W zależności od pożądanego stopnia dokładności, typy rolnicze gospodarstw dzieli się na 8 typów ogólnych, 21 typów podstawowych i 61 typów szczegółowych

\section{Metodyczne aspekty opracowania}

Celem niniejszego opracowania jest próba ukazania zakresu efektywności wykorzystania zasobów produkcyjnych w gospodarstwach o różnych typach rolniczych.

Materiałem badawczym były dane o gospodarstwach, które prowadziły rachunkowość rolną dla potrzeb Instytutu Ekonomiki Rolnictwa i Gospodarki Żywnościowej. Szczegółową analizą objęto rok 2016.

Podstawowymi kategoriami produkcyjno-ekonomicznymi przyjętymi dla potrzeb procesu badawczego były: wartość produkcji ogółem oraz dochód z gospodarstwa rolniczego. Obliczeń tych kategorii dokonano metodą stosowaną w europejskim systemie rachunkowości rolnej FADN (Farm Accountancy Date Network) ${ }^{4}$.

Oceny efektywności gospodarowania w poszczególnych typach gospodarstw dokonano na podstawie produktywności i dochodowości ziemi, pracy i kapitału.

Produktywność obliczono jako wartość produkcji rolniczej przypadającą na 1 ha UR, na 1 jednostkę przeliczeniową pracy AWU i na 1000 zł wartości rzeczowych środków trwałych i obrotowych. Dochodowość ukazano jako wartość dochodu z gospodarstwa rolniczego przypadającą na 1 ha UR, na 1 jednostkę przeliczeniową pracy AWU i na 1000 zł wartości rzeczowych środków trwałych i obrotowych. Poszczególne wielkości ukazano w przeliczeniu na jedno gospodarstwo w zł. Skalę zróżnicowania przedstawiono w ujęciu procentowym.

Dodatkowo ukazano także zakres oddziaływania płatności bezpośrednich do gruntów rolnych w zależności od typu rolniczego gospodarstwa. Ich wielkość rozpatrywano w relacji do dochodu z gospodarstwa rolniczego.

\section{Charakterystyka badanych gospodarstw}

Średni obszar badanego gospodarstwa w 2016 roku wynosił 19,5 ha UR. Analizowane gospodarstwa reprezentowały różne typy rolnicze. W próbie badawczej polskiego FADN dominującym typem były gospodarstwa, dla których główną działalnością biorącą udział w tworzeniu wartości standardowej produkcji były uprawy polowe. Ich udział

\footnotetext{
${ }^{2}$ M. Bocian, I. Cholewa, R. Tarasiuk, Współczynniki Standardowej Produkcji dla celów Wspólnotowej Typologii Gospodarstw Rolnych IERiGŻ Warszawa 2017, s 43-51.

${ }^{3}$ Wyniki Standardowe 2016 uzyskane przez gospodarstwa rolne uczestniczące w Polskim FADN. IERiGŻ, Warszawa 2017, s. 9-11.

${ }^{4}$ Z Floriańczyk, B. Malanowska, D. Osuch, M. Bocian: Opis realizacji planu wyboru próby gospodarstw rolnych dla Polskiego FADN. IERiGŻ, Warszawa 2017, s. 8-15.
} 
wynosił 31,6\%. Na drugim miejscu pod względem liczebności znalazły się gospodarstwa o typie mieszanym. Ten typ rolniczy stanowił $28,1 \%$ ogółu gospodarstw. Udział pozostałych typów rolniczych wynosił odpowiednio: krowy mleczne - 22,3\%, trzoda chlewna $-5,7 \%$, zwierzęta trawożerne $-5,3 \%$, uprawy trwałe $-3,6 \%$, uprawy ogrodnicze $2,7 \%$. Stosunkowo najmniejszą grupę $(0,7 \%)$ stanowiły gospodarstwa drobiarskie.

Poszczególne grupy gospodarstw wydzielone ze względu na typ rolniczy charakteryzowały się dużym zróżnicowaniem wyników produkcyjnych (tabela 1).

Tabela 1. Charakterystyka gospodarstw według typu rolniczego w 2016 roku

\begin{tabular}{|c|c|c|c|c|c|c|c|c|}
\hline Wyszczególnienie & $\begin{array}{l}\text { Uprawy } \\
\text { polowe }\end{array}$ & $\begin{array}{l}\text { Uprawy } \\
\text { ogrod- } \\
\text { nicze }\end{array}$ & $\begin{array}{l}\text { Uprawy } \\
\text { trwałe }\end{array}$ & $\begin{array}{l}\text { Krowy } \\
\text { mlecz- } \\
\text { ne }\end{array}$ & $\begin{array}{l}\text { Zwierz. } \\
\text { trawo- } \\
\text { żerne }\end{array}$ & $\begin{array}{c}\text { Trzoda } \\
\text { chlew- } \\
\text { na }\end{array}$ & Drób & $\begin{array}{l}\text { Mie- } \\
\text { szane }\end{array}$ \\
\hline Liczba gospodarstw & 3893 & 337 & 437 & 2749 & 651 & 704 & 85 & 3446 \\
\hline Powierzchnia UR w ha & 25,8 & 6,4 & 8,5 & 21,5 & 17,7 & 20,4 & 27,0 & 17,7 \\
\hline $\begin{array}{l}\text { Nakłady pracy ogółem } \\
\text { w AWU na } 1 \text { gospodar- } \\
\text { stwo }\end{array}$ & 1,59 & 2,58 & 1,99 & 1,78 & 1,47 & 1,64 & 3,67 & 1,58 \\
\hline Plony pszenicy w dt/ha & 56,4 & 47,7 & 41,3 & 46,9 & 43,8 & 52,1 & 51,3 & 51,2 \\
\hline $\begin{array}{l}\text { Wydajność mleczna } \\
\text { krów w litrach }\end{array}$ & 4422 & 2542 & 2421 & 5505 & 4273 & 4682 & 2500 & 5801 \\
\hline $\begin{array}{l}\text { Obsada zwierząt w LU/ } \\
\text { ha }\end{array}$ & 0,24 & 0,17 & 0,04 & 1,81 & 1,09 & 0,52 & 0,06 & 1,39 \\
\hline $\begin{array}{l}\text { Wielkość ekonomiczna } \\
\text { gospodarstwa w euro }\end{array}$ & 20556 & 49147 & 15211 & 31164 & 15047 & 52934 & 171498 & 19498 \\
\hline
\end{tabular}

Źródło: obliczenia własne na podstawie Wyniki Standardowe 2016 uzyskane przez gospodarstwa rolne uczestniczące w Polskim FADN. IERiGŻ, Warszawa 2017, s. 42-49.

Typ rolniczy okazał się czynnikiem różnicującym zarówno obszar jak i wyniki produkcyjne gospodarstw. Największą powierzchnią użytków rolnych odznaczały się gospodarstwa nastawione na chów drobiu $(27,0 \mathrm{ha})$ i uprawy polowe $(25,8 \mathrm{ha})$. Istotną rolę obszar odgrywał także w gospodarstwach, w których dominującą działalnością biorącą udział w tworzeniu wartości standardowej produkcji był chów krów mlecznych (21,5 ha) oraz trzody chlewnej $(20,4 \mathrm{ha})$. Stosunkowo najmniejszymi były gospodarstwa specjalizujące się w uprawach ogrodniczych. Średni obszar wynosił tutaj zaledwie 6,4 ha UR.

Zgodnie z oczekiwaniami najlepsze wyniki dotyczące produkcji roślinnej osiagano w gospodarstwach nastawionych na uprawy polowe. Średni plon pszenicy wynosił tutaj $56,4 \mathrm{dt} /$ ha. Najwyższą obsadę zwierząt posiadały gospodarstwa specjalizujące się w chowie krów mlecznych. Wynosiła ona tutaj 1,81 LU na ha. Z kolei gospodarstwami o najwyższych nakładach pracy ogółem były gospodarstwa drobiarskie $\mathrm{i}$ ogrodnicze (odpowiednio 3,67 i 2,58 jednostki przeliczeniowej pracy AWU na 1gospodarstwo).

Istotnym parametrem oceny siły ekonomicznej gospodarstw w UE jest wielkość ekonomiczna. Określana jest ona na podstawie sumy Standardowych Produkcji uzyskanych ze wszystkich działalności rolniczych występujących $\mathrm{w}$ danym gospodarstwie rolnym. Wyrażana jest ona bezpośrednio w euro. W śród analizowanych gospodarstw największą wielkością ekonomiczną odznaczały się gospodarstwa specjalizujące się w chowie drobiu (171,5 tys. euro) i trzody chlewnej (52,9 tys. euro). Niską wielkością ekonomiczną odznaczała się grupa gospodarstw nastawionych na uprawy trwałe wieloletnie. 


\section{Wielkość produktywności ziemi, pracy i kapitału}

W metodzie FADN w rachunku produkcji uwzględniana jest sprzedaż produktów, różnica stanu zapasów, zużycie wewnętrzne i przekazanie do gospodarstwa domowego. Dzięki takiemu podejściu uzyskuje się pełne odzwierciedlenie obrotu produktami gotowymi, przekazania nieodpłatne oraz transfery produktów w ramach działalności operacyjnej gospodarstwa rolnego. Wartość zużycia wewnętrznego produktów potencjalnie towarowych nie wpływa na poziom określonych nadwyżek ekonomicznych, gdyż znajduje się ona po obu stronach rachunku (produkcyjnej i kosztowej).

Wartość produkcji rolniczej ogółem w poszczególnych typach gospodarstw przedstawia rysunek 1 .

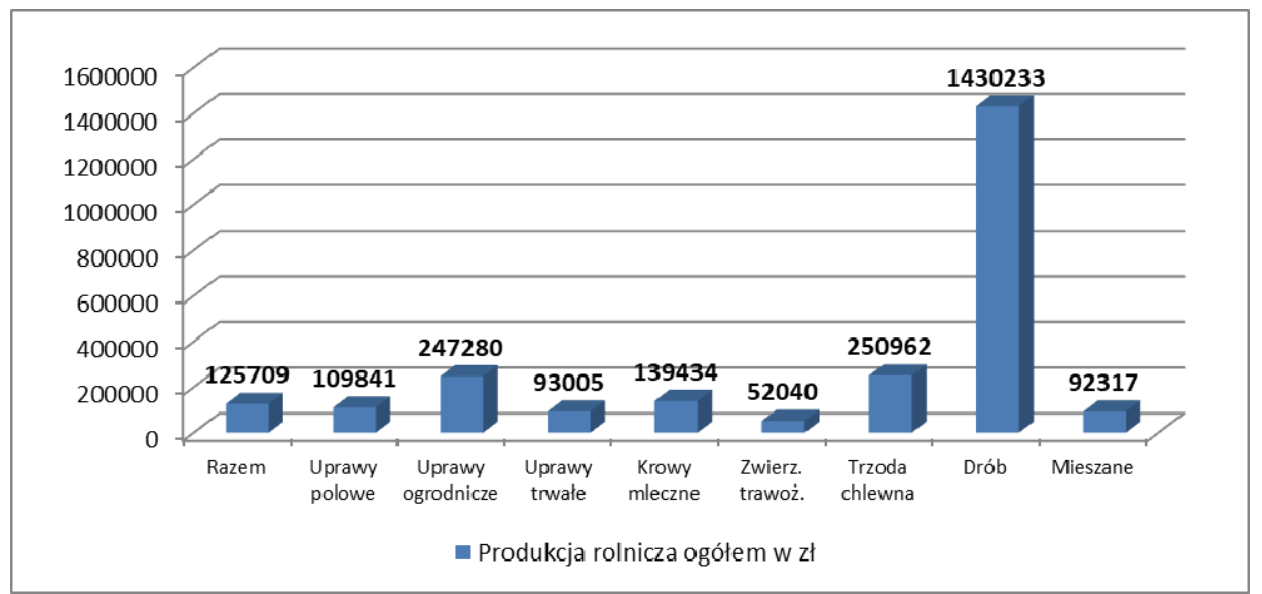

Rysunek 1. Wartość produkcji rolniczej ogółem według typów gospodarstw w roku 2016 Źródło: obliczenia własne na podstawie Wyniki Standardowe 2016 uzyskane przez gospodarstwa rolne uczestniczące w Polskim FADN. IERiGŻ, Warszawa 2017, s. 42-49.

Największą wartością produkcji rolniczej w przeliczeniu na jedno gospodarstwo odznaczały się gospodarstwa nastawione na chów drobiu. Jej wartość tutaj o 5,7 razy przewyższała tą odnotowaną w gospodarstwach specjalizujących się w chowie trzody chlewnej. Podobną wielkość tej kategorii produkcji osiągano w gospodarstwach ogrodniczych (247,3 tys. zł). Najniższą wartość produkcji rolniczej odnotowano w gospodarstwach z dominacją zwierząt trawożernych jako głównego profilu produkcji. Wyniosła o na tutaj niespełna 52,0 tys. zł.

Potencjał wytwórczy gospodarstwa rolnego tworzą trzy podstawowe czynniki produkcji: ziemia, praca i kapitał. Czynniki te oraz występujące między nimi relacje określają rozmiary możliwej do osiągnięcia produkcji ${ }^{5}$.

W tym miejscu warto zwrócić uwagę na różnicę występującą między pojęciami: produkcyjność i produktywność, często traktowanymi jako synonimy. Produkcyjność w odróżnieniu od produktywności wyrażana jest w jednostkach naturalnych co pozwala

\footnotetext{
${ }^{5}$ B. Klepacki, Produkcyjne i ekonomiczne przystosowania gospodarstw prywatnych do zmian warunków gospodarowania. Wyd. SGGW, Warszawa 1997, 124-126.
} 
określić wydajność technologiczną danego czynnika produkcji. Pojęcie produktywności oznacza natomiast produkcję w przeliczeniu na jednostkę czynnika produkcji wyrażoną w pieniądzu.

Tabela 2. Poziom i zróżnicowanie produktywności według typów gospodarstw w roku 2016 $(100,0 \%=$ typ rolniczy-uprawy polowe $)$

\begin{tabular}{|c|c|c|c|c|c|c|c|c|}
\hline Wyszczególnienie & $\begin{array}{l}\text { Uprawy } \\
\text { polowe }\end{array}$ & $\begin{array}{l}\text { Upra- } \\
\text { wy } \\
\text { ogrod- } \\
\text { nicze }\end{array}$ & $\begin{array}{l}\text { Upra- } \\
\text { wy } \\
\text { trwałe }\end{array}$ & $\begin{array}{c}\text { Krowy } \\
\text { mlecz- } \\
\text { ne }\end{array}$ & $\begin{array}{c}\text { Zwierz. } \\
\text { trawo- } \\
\text { żerne }\end{array}$ & $\begin{array}{l}\text { Trzoda } \\
\text { chlewna }\end{array}$ & Drób & $\begin{array}{l}\text { Mie- } \\
\text { szane }\end{array}$ \\
\hline & \multicolumn{8}{|c|}{ Wartość w zł } \\
\hline Produktywność ziemi & 4257 & 38638 & 10941 & 6485 & 2940 & 12302 & 52971 & 5216 \\
\hline Produktywność pracy & 69082 & 95845 & 46736 & 78334 & 35401 & 170722 & 389709 & 58428 \\
\hline \multirow[t]{2}{*}{$\begin{array}{l}\text { Produktywność kapita- } \\
\text { łu }\end{array}$} & 136 & 427 & 138 & 147 & 79 & 248 & 722 & 148 \\
\hline & \multicolumn{8}{|c|}{ Zróżnicowanie w \% } \\
\hline Produktywność ziemi & 100,0 & 907,6 & 257,0 & 152,3 & 113,4 & 289,0 & 1244,3 & 122,5 \\
\hline Produktywność pracy & 100,0 & 138,7 & 67,7 & 113,4 & 51,2 & 247,1 & 564,1 & 84,6 \\
\hline $\begin{array}{l}\text { Produktywność kapita- } \\
\text { łu }\end{array}$ & 100,0 & 314,0 & 101,5 & 108,1 & 58,1 & 182,3 & 530,8 & 108,8 \\
\hline
\end{tabular}

Źródło: obliczenia własne na podstawie Wyniki Standardowe 2016 uzyskane przez gospodarstwa rolne uczestniczące w Polskim FADN. IERiGŻ, Warszawa 2017, s. 42-49.

Określając produktywność ziemi użytkowanej rolniczo wartością produkcji rolniczej na 1 ha UR można zauważyć, że wśród analizowanych gospodarstw jej najwyższa wartość przypadała na gospodarstwa drobiarskie i ogrodnicze (tabela 2). Była ona tam ponad 12 krotnie i 9 krotnie wyższa niż w gospodarstwach o typie rolniczym uprawy polowe. Miało to związek ze skalą intensywności produkcji prowadzonej w tych gospodarstwach. Ponad 2,8 razy wyższa, w porównaniu z gospodarstwami o typie uprawy polowe, produktywność ziemi była w gospodarstwach nastawionych na chów trzody chlewnej.

Analizując poziom produktywności pracy - mierzony wartością produkcji rolniczej przypadającej na jednostkę przeliczeniowa pracy (AWU), można stwierdzić, iż zakres zróżnicowania jej wartości w poszczególnych typach gospodarstw był mniejszy niż w przypadku produktywności ziemi. Typem rolniczym o najwyższej produktywności pracy były gospodarstwa zajmujące się chowem drobiu oraz trzody chlewnej. W tych gospodarstwach, ten typ produktywności ponad 5,6 oraz 2,4 razy przewyższał produktywność pracy występująca $\mathrm{w}$ gospodarstwach specjalizujących się w uprawach polowych.

Produktywność kapitału wyrażona została wartością produkcji rolniczej przypadającej na 1000 zł wartości rzeczowych środków trwałych i obrotowych. Spośród wszystkich, analizowanych rodzajów produktywności to właśnie produktywność kapitału odznaczała się najmniejszą skalą zróżnicowania w zależności od typu gospodarstwa. Najniższy poziom produktywności kapitału posiadały gospodarstwa, w których dominował chów zwierząt trawożernych. Najwyższy poziom tego rodzaju produktywności, podobnie jak $\mathrm{w}$ przypadku produktywności ziemi, osiagały gospodarstwa, w których dominującą działalnością, biorącą udział w tworzeniu ogólnej standardowej produkcji, był chów drobiu i uprawy ogrodnicze. 


\section{Zróżnicowanie poziomu dochodowości w różnych typach gospodarstw}

Przy uwzględnieniu obecnych uwarunkowań konkurencyjność w rolnictwie jest określana przez dwa czynnik: czynnik instytucjonalny i czynnik mikroekonomiczny. Czynnik instytucjonalny w coraz większym stopniu koncentruje swe oddziaływanie na procesach społecznych związanych z rozwojem wsi i rolnictwa. Czynnik mikroekonomiczny to efektywność produkcji będąca podstawą dochodów producenta żywności ${ }^{6}$.

Poziom dochodu z gospodarstwa w poszczególnych typach gospodarstw przedstawia rysunek 2 .

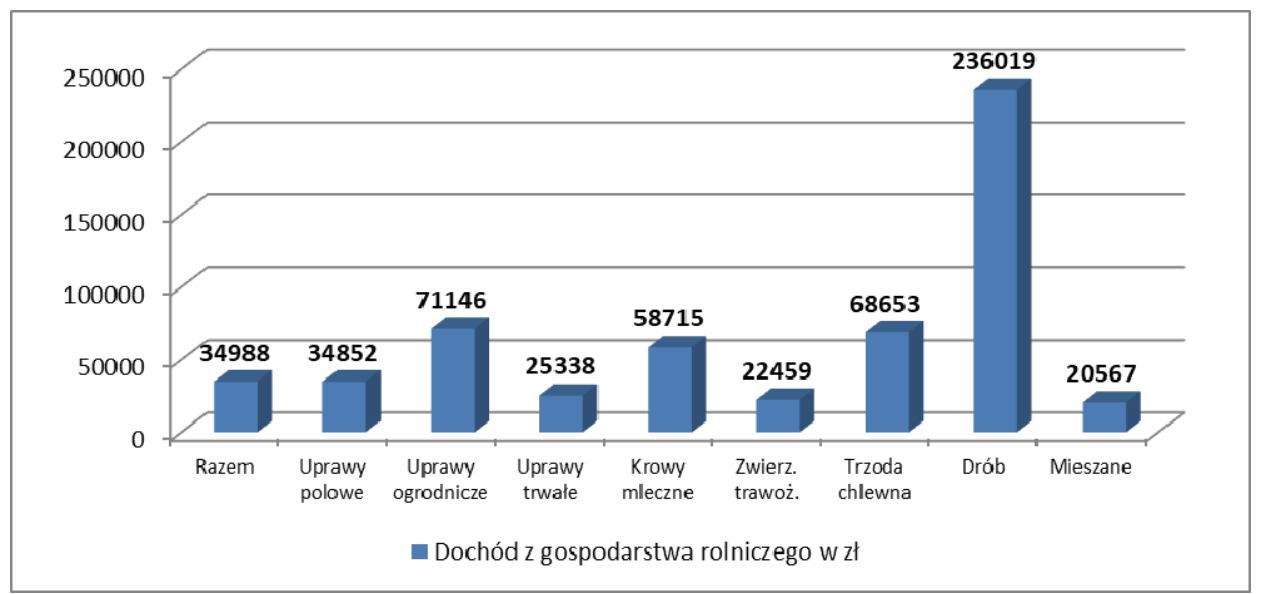

Rysunek 2. Poziom dochodu rolniczego według typów gospodarstw w roku 2016

Źródło: obliczenia własne na podstawie Wyniki Standardowe 2016 uzyskane przez gospodarstwa rolne uczestniczące w Polskim FADN. IERiGŻ, Warszawa 2017, s. 46-49.

Wartość produkcji rolniczej osiaganej przez poszczególne typy analizowanych gospodarstw w sposób oczywisty determinowała ich wyniki ekonomiczne. Najwyższym poziomem dochodu z gospodarstwa rolniczego wyróżniały się gospodarstwa trudniące się chowem drobiu i gospodarstwa ogrodnicze. Średni poziom tej kategorii dochodu w przeliczeniu na 1 gospodarstwo wynosił tutaj odpowiednio ponad 236,0 tys. zł i 71,1 tys. zł. Najsłabiej pod względem ekonomicznym w tym zestawieniu wypadały gospodarstwa o typie mieszanym. Ich dochód na 1 gospodarstwo wynosił w 2016 roku niespełna 20,6 tys. zt.

Wielkość i relacje pomiędzy czynnikami produkcji: ziemią, pracą i kapitałem w sposób zasadniczy wpływają na poziom uzyskiwanego przez rolników dochodu. W odniesieniu do poszczególnych typów gospodarstw powoduje to zróżnicowanie ich dochodowości (tabela 3 ).

${ }^{6}$ J.S. Zegar (red.), Z badań nad rolnictwem społecznie zrównoważonym. Program Wieloletni 2015-2019. Nr 39, PIB IERiGŻ, Warszawa 2017, s. 9-21. 
Tabela 3. Poziom i zróżnicowanie dochodowości według typów gospodarstw w roku 2016 $(100,0 \%=$ typ rolniczy-uprawy polowe $)$

\begin{tabular}{|c|c|c|c|c|c|c|c|c|}
\hline Wyszczególnienie & $\begin{array}{l}\text { Uprawy } \\
\text { polowe }\end{array}$ & $\begin{array}{l}\text { Upra- } \\
\text { wy } \\
\text { ogrod- } \\
\text { nicze }\end{array}$ & $\begin{array}{l}\text { Upra- } \\
\text { wy } \\
\text { trwałe }\end{array}$ & $\begin{array}{c}\text { Krowy } \\
\text { mlecz- } \\
\text { ne }\end{array}$ & $\begin{array}{c}\text { Zwierz. } \\
\text { trawo- } \\
\text { żerne }\end{array}$ & $\begin{array}{l}\text { Trzoda } \\
\text { chlewna }\end{array}$ & Drób & $\begin{array}{c}\text { Miesza- } \\
\text { ne }\end{array}$ \\
\hline & \multicolumn{8}{|c|}{ Wartość w zł } \\
\hline Dochodowość ziemi & 1355 & 11117 & 2981 & 2731 & 1269 & 3365 & 8741 & 1162 \\
\hline Dochodowość pracy & 21982 & 27576 & 12733 & 32986 & 15278 & 41862 & 64310 & 13017 \\
\hline \multirow[t]{2}{*}{ Dochodowość kapitału } & 43 & 123 & 38 & 62 & 34 & 68 & 119 & 33 \\
\hline & \multicolumn{8}{|c|}{ Zróżnicowanie w \% } \\
\hline Dochodowość ziemi & 100,0 & 820,4 & 220,0 & 201,5 & 93,6 & 248,3 & 645,1 & 85,8 \\
\hline Dochodowość pracy & 100,0 & 125,4 & 57,9 & 150,0 & 69,5 & 190,4 & 292,6 & 59,2 \\
\hline Dochodowość kapitału & 100,0 & 286,0 & 88,4 & 144,1 & 79,1 & 158,1 & 276,7 & 76,7 \\
\hline
\end{tabular}

Zródło: obliczenia własne na podstawie Wyniki Standardowe 2016 uzyskane przez gospodarstwa rolne uczestniczące w Polskim FADN. IERiGŻ, Warszawa 2017, s. 46-49.

Obserwowane w badanych gospodarstwach duże zróżnicowanie produktywności pomiędzy typami rolniczymi, w przypadku poszczególnych rodzajów dochodowości miało już nieco mniejszy zakres. Najwyższy poziom dochodowości ziemi i kapitału osiaggano w gospodarstwach specjalizujących się w uprawach ogrodniczych, natomiast dochodowości pracy $\mathrm{w}$ gospodarstwach nastawionych na chów drobiu. W porównaniu do gospodarstw o typie uprawy polowe poszczególne rodzaje dochodowości były większe odpowiednio o 8,2-razy, 2,9-razy i 2,8-razy.

Gospodarstwa o typie mieszanym, posiadające 28,1\% udziału w ogólnej liczbie analizowanych gospodarstw, na tle pozostałych typów odznaczały się niską efektywnością wykorzystania zasobów produkcyjnych. Dochodowość ziemi wynosiła tutaj w 2016 roku zaledwie 1162 zł na 1 ha. Również dochodowość pracy i kapitału w gospodarstwach, w których brak było wyraźnej dominacji jednej z działalności w tworzeniu ogólnej wartości standardowej produkcji, była niższa o odpowiednio 40,8\% i 23,3\% niż w gospodarstwach specjalizujących się w uprawach polowych. Wszystko to pogarszało pozycję gospodarstw o typie mieszanym w ich konkurencji o podstawowe czynniki produkcji w rolnictwie.

\section{Zakres oddziaływania płatności bezpośrednich na sytuację ekonomiczna gospodarstw}

Istotnym elementem w finansowaniu działalności rolniczej gospodarstw są środki rozdysponowywane jako realizacja Wspólnej Polityki Rolnej UE. Są to środki przekazywane w ramach dopłat bezpośrednich i funduszy strukturalnych. W latach 1994-2016 rozdystrybuowano na programy pomocowe za pośrednictwem ARiMR środki finansowe w wysokości 279,4 mld zł, z czego 26,0 mld zł w 2016 r. Liczba beneficjentów płatności bezpośrednich obsługiwanych przez Agencję wyniosła $1.35 \mathrm{mln}$. W sumie w 2016 roku na ten cel wypłacono 4,4 mld zł obejmując 14 mln ha upraw ${ }^{7}$.

Typ rolniczy różnicował także wielkość płatności bezpośrednich do gruntów rolnych analizowanych gospodarstw (rysunek 3). Wynikało to ze zróżnicowania obszarowego gospodarstw oraz z różnego poziomu płatności stosowanych do powierzchni określonych roślin uprawnych.

\footnotetext{
${ }^{7}$ Sprawozdanie z działalności Agencji Restrukturyzacji i Modernizacji Rolnictwa za 2016 rok. Departamencie Analiz i Sprawozdawczości ARiMR Warszawa 2017. s.28-32.
} 


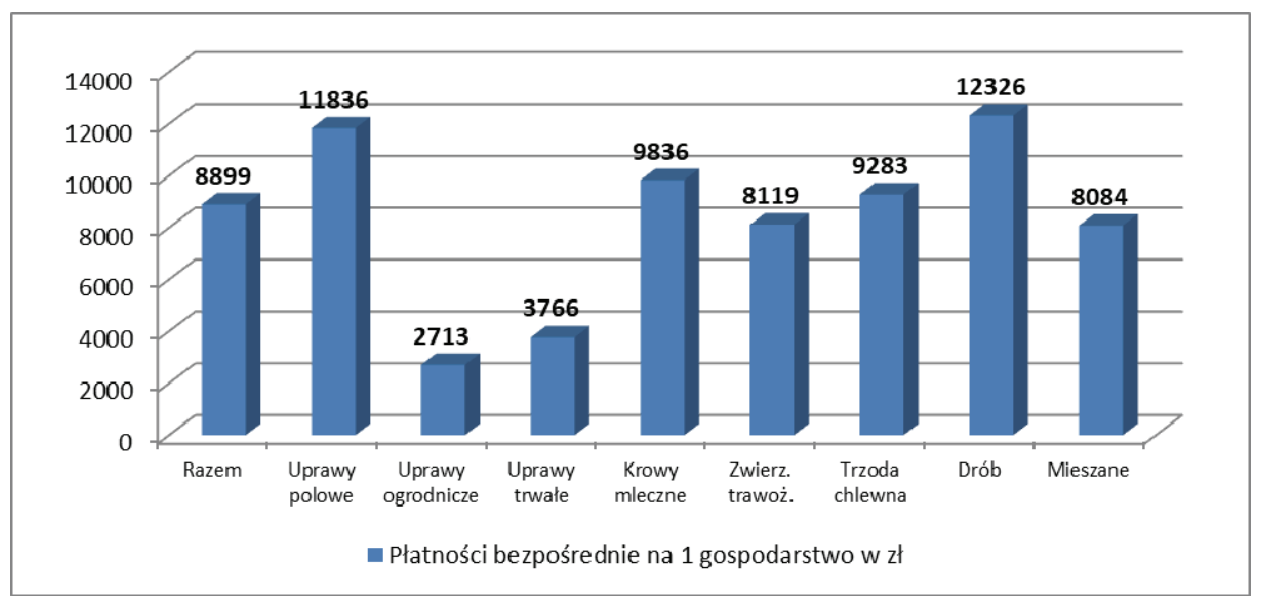

Rysunek 3. Wartość płatności bezpośrednich w różnych typach gospodarstw w 2016 roku [w zł] Źródło: obliczenia własne na podstawie Wyniki Standardowe 2016 uzyskane przez gospodarstwa rolne uczestniczące w Polskim FADN. IERiGŻ, Warszawa 2017, s. 46-51.

Najwięcej środków pochodzących z płatności bezpośrednich trafiła do gospodarstw specjalizujących się $\mathrm{w}$ chowie drobiu $\mathrm{i}$ w uprawach polowych. W przeliczeniu na jedno gospodarstwo były to kwoty odpowiednio12,3 tys. zł i 11,8 tys. zł. W gospodarstwach ogrodniczych średnia wielkość płatności wyniosła 2,7 tys. zł. Duże zróżnicowanie wynikało z wielkości obszarowej gospodarstw. Średni obszar gospodarstw należących do tych typów rolniczych wynosił odpowiednio 27,0 ha, 25,8 ha i 6,0 ha.

Zakres oddziaływania płatności bezpośrednich do gruntów rolnych na sytuację dochodową gospodarstw przedstawia rysunek 4.

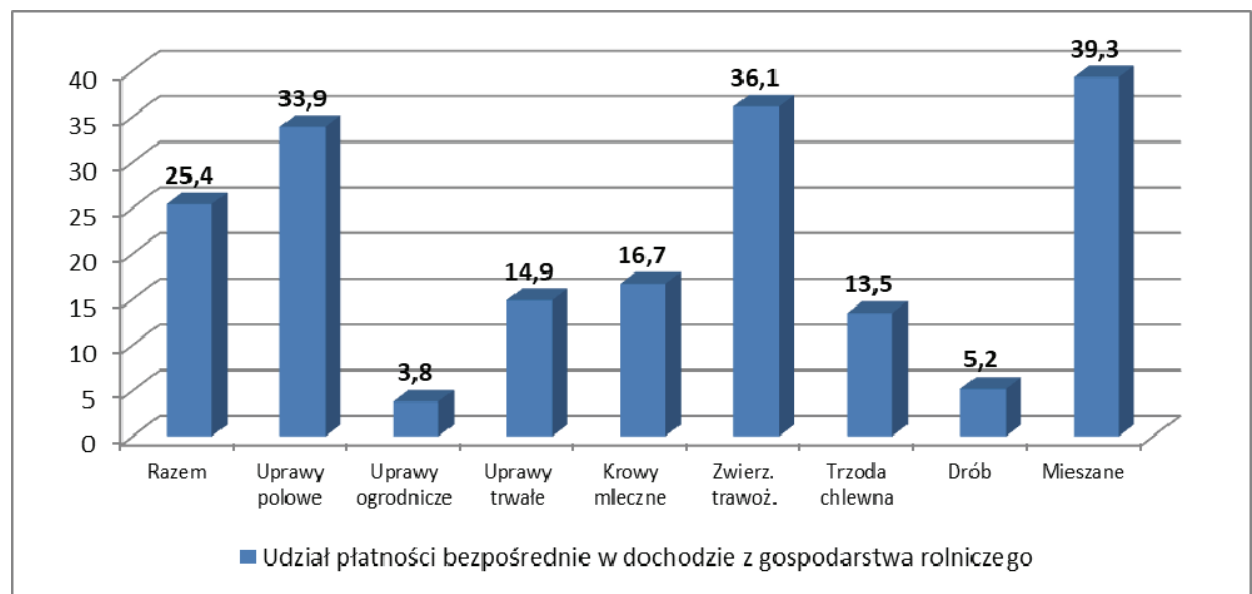

Rysunek 4. Udział płatności bezpośrednich w dochodzie z gospodarstwa rolniczego w różnych typach gospodarstw w 2016 roku [w \%]

Źródło: obliczenia własne na podstawie Wyniki Standardowe 2016 uzyskane przez gospodarstwa rolne uczestniczące w Polskim FADN. IERiGŻ, Warszawa 2017, s. 46-51. 
Najszerszy zakres oddziaływania płatności bezpośrednich na dochody rolników zaznaczył się w przypadku gospodarstw o typie rolniczym mieszanym i gospodarstw nastawionych na chów zwierząt trawożernych. Udział tej formy płatności w dochodzie $\mathrm{z}$ gospodarstwa rolniczego wynosił tutaj odpowiednio 39,3\% i 36,1\%.

Istotną pozycje $\mathrm{w}$ dochodach środki $\mathrm{z}$ płatności bezpośrednich posiadały także $\mathrm{w}$ gospodarstwach, w których dominującą działalnością były uprawy polowe. Ich udział wynosił tutaj 33,9\%.

Zdecydowanie najmniejsze oddziaływanie na dochody ten typ płatności posiadał w gospodarstwach zajmujących się chowem drobiu i w gospodarstwach ogrodniczych. W tym przypadku wysoki poziom osiaganych dochodów miał bezpośredni związek z intensywnością produkcji. Jak pokazała analiza były to bowiem gospodarstwa o wysokim poziomie efektywności wykorzystania zasobów ziemi pracy i kapitału.

\section{Podsumowanie}

Typ rolniczy stanowi obok wielkości ekonomicznej podstawę klasyfikacji gospodarstw rolnych w krajach Unii Europejskiej. Jest on również parametrem różnicującym wyniki produkcyjne i ekonomiczne gospodarstw.

Przeprowadzona analiza wykazała, iż typ rolniczy wpływa również na zróżnicowanie zakresu efektywności wykorzystania podstawowych czynników produkcji: ziemi pracy i kapitału. Intensywna produkcja prowadzona $\mathrm{w}$ gospodarstwach drobiarskich $\mathrm{i}$ ogrodniczych sprawiała, iż to właśnie one osiągnęły w 2016 roku najwyższą produktywność i dochodowość ziemi i kapitału. W odniesieniu do trzeciego czynnika produkcji (pracy), jego istotność potwierdziła się także w gospodarstwach nastawionych na chów trzody chlewnej. Tego typu działalność pozwalała efektywnie zagospodarować zasoby ludzkie.

Zupełnie inaczej sytuacja wyglądała w przypadku gospodarstw, w których w tworzeniu ogólnej wartości standardowej produkcji dominowały uprawy polowe. Odznaczały się one bowiem najniższą produktywnością ziemi. Niskie wartości przyjmowała tu także dochodowość tego czynnika produkcji. Obserwowane duże zróżnicowanie produktywności pomiędzy typami rolniczymi, w przypadku poszczególnych rodzajów dochodowości miało już nieco mniejszy zakres.

Gospodarstwach o typie mieszanym, w których brak było wyraźnej dominacji jednej działalności w tworzeniu ogólnej wartości standardowej produkcji oraz te $\mathrm{z}$ dominacja zwierząt trawożernych lub upraw trwałych, na tle pozostałych analizowanych typów osiaggały najniższy poziom produkcji rolniczej. Niski był również tutaj poziom dochodu z gospodarstwa rolniczego. Konsekwencją takiej sytuacji, w tych typach gospodarstw, była niska efektywność wykorzystania zasobów. Szansą okazywały się wówczas płatności bezpośrednie i środki z funduszy UE. Oddziaływanie tych strumieni finansowych na dochody było tutaj najsilniejsze.

\section{Bibliografia}

Bocian M., Cholewa I., Tarasiuk R., Współczynniki Standardowej Produkcji dla celów Wspólnotowej Typologii Gospodarstw Rolnych IERiGŻ Warszawa 2017.

Committee for the farm accountancy data network. Typology handbook. Brussels, 2016. 
Floriańczyk Z., Malanowska B., Osuch D., Bocian M.: Opis realizacji planu wyboru próby gospodarstw rolnych dla Polskiego FADN. IERiGŻ, Warszawa 2017.

Klepacki B., Produkcyjne i ekonomiczne przystosowania gospodarstw prywatnych do zmian warunków gospodarowania. Wyd. SGGW, Warszawa 1997.

Sprawozdanie z działalności Agencji Restrukturyzacji i Modernizacji Rolnictwa za 2016 rok. Departamencie Analiz i Sprawozdawczości ARiMR Warszawa 2017. s.28-32.

Wyniki Standardowe 2016 uzyskane przez gospodarstwa rolne uczestniczące w Polskim FADN. IERiGŻ, Warszawa 2017.

Zegar J.S. (red.), Z badań nad rolnictwem społecznie zrównoważonym. Program Wieloletni 20152019. Nr 39, PIB IERiGŻ, Warszawa 2017.

\section{Summary}

The agricultural type is one of the criteria used to characterize a farm in the EU. The purpose of this study is to show the range of the effectiveness of the use of production resources in various types of farms. The productivity and profitability of land, labor and capital were used to assess the effectiveness of management in particular types of farms. Individual sizes are shown per one household in PLN. The scale of diversification is presented in percentage terms. The analysis carried out showed that intensive production carried out on poultry and horticultural farms made them the most productive and profitable land and capital in 2016.

Key words: agricultural type, productivity, profitability.

Informacja o autorach:

\section{Dr inż. Agata Marcysiak}

Katedra Ekonomii

Wydział Nauk Ekonomicznych i Prawnych

Uniwersytet Przyrodniczo-Humanistyczny w Siedlcach

ul Żytnia 17/19

08-110 Siedlce

agata.marcysiak@uph.edu.pl

Dr inż. Adam Marcysiak

Katedra Logistyki

Wydział Nauk Ekonomicznych i Prawnych

Uniwersytet Przyrodniczo-Humanistyczny w Siedlcach

ul Żytnia 17/19

08-110 Siedlce

adam.marcysiak@uph.edu.pl 